\title{
Potensialitas dan keterbatasan inovasi morfologis dalam bahasa Indonesia Contoh kombinasi afiks keter-/-an
}

\author{
JÉRÔME SAMUEL
}

\begin{abstract}
This paper examines with a particular affixe (keter-/-an) consisting in two primary affixes. Through the analyse of terms coined by the Pusat Bahasa and spontaneous terms, the paper distinguishes between "double" and "complex" affixation, corresponding to different operating modes of affixation. The first deals with an already affixed and lexicalized word, then reaffixed and relexicalized. The second, almost only found in documents produced by the Pusat Bahasa, refers to a base getting a first affix in a poorly (or not) lexicalized form, constituting no more than a morphological stage towards the wished form, which is intent as lexicalized. Complex affix keter-R-an is basically a morphological calque and the author argues that it has been promoted and used during New Order on an ideological basis, as a mean to modernize Indonesian terminology by keeping its shape indigenous rather than by direct borrowing of English terms.
\end{abstract}

KEYWORDS

Linguistik Indonesia (Indonesian linguistics), terminology (terminology), politik istilah (language policy).

\subsection{PENDAHULUAN: PENGEMBANGAN PERISTILAHAN}

Pada pertengahan abad dua puluh, Indonesia menghadapi masalah pemerlengkapan kosa kata di sejumlah bidang pengetahuan. Situasi yang kurang lebih sama terjadi di semua negara berkembang yang saat merdeka belum mempunyai literatur ilmu dan teknologi modern dan yang mayoritas penduduknya kurang atau tidak menguasai bahasa asing sebagai bahasa pengantar ilmu dan teknologi (selanjutnya disebut il-tek). Usaha-usaha di

JÉRÔME SAMUEL is lecturer in Indonesian at the Institut National des Langues et Civilisations Orientales (Paris), and also researcher at the Centre Asie du Sud-Est (CNRS-EHESS, Paris). Since the end of the 1990's his research has covered various linguistic and terminological policy issues with regard to the Indonesian language. At present his research is focused on the creation, development and use of terminology related to science and technology outside the formal circles of the Pusat Bahasa and other governmental institutions. E-mail: jeromesamuel@free.fr.

(C) 2009 Fakultas Ilmu Pengetahuan Budaya, Universitas Indonesia 
bidang terminologi sudah mulai dikerjakan sejak tahun 1942 berdasarkan berbagai prinsip terminologi yang sempat dipikirkan dan dirumuskan sebelumnya. Kemudian diteruskan dalam wadah Indonesia pascakolonial melalui berbagai lembaga resmi kebahasaan dan peristilahan. Tugas lembagalembaga itu dianggap sebagai sebuah keperluan mutlak dan mulia demi masa depan bangsa Indonesia, dan usahanya ikut mengungkapkan sebuah perasaan nasional yang kuat.

Sejak 1972 usaha terminologi resmi di Indonesia ditangani oleh Pusat Pembinaan dan Pengembangan Bahasa, ${ }^{1}$ di bawah Departemen Pendidikan dan Kebudayaan, kemudian Departemen Pendidikan Nasional. Dalam hal ini, Pusat Bahasa ${ }^{2}$ bekerja sama dengan dua negara penutur bahasa Melayu, ${ }^{3}$ yaitu Malaysia, dan Brunei Darussalam, melalui Majelis Bahasa Brunei Indonesia Malaysia (selanjutnya MABBIM). Pusat Bahasa beserta mitra kerjanya berusaha untuk :

(1) memungkinkan dan mengatur penerjemahan timbal balik antara bahasa Melayu dan bahasa Inggris sebagai bahasa pengantar il-tek yang pertama di dunia masa kini,

(2) mengadakan peristilahan berbagai bidang ilmu dan teknologi dalam bahasa nasional mereka (pemerlengkapan istilah), dan

(3) menyeragamkan atau, paling sedikit, merapatkan, peristilahan resmi di Indonesia, Malaysia, dan Brunei Darussalam (penyelarasan istilah).

Pada dasarnya, Pusat Bahasa dan pihak lainnya menciptakan dan mengembangkan peristilahan terjemahan, di mana bahasa Inggris merupakan bahasa sumber dan bahasa Melayu bahasa sasaran. Secara garis besar, selama dua dasawarsa proses kerja mengikuti tahap-tahap berikut: ${ }^{4}(1)$ bidang-bidang ilmu yang ingin digarap bersama dipilih oleh MABBIM, (2) ahli-ahli terminologi dan pakar ilmu dan teknologi MABBIM menentukan istilah yang diperlukan, dengan bertolak dari literatur yang ada dalam bahasa sumber, (3) masingmasing lembaga anggota MABBIM (Pusat Bahasa dari Indonesia, Dewan Bahasa dan Pustaka dari Malaysia dan Brunei Darussalam) mencari padanan yang sudah ada dalam bahasa sasaran atau menciptakannya, (4) ketiga pihak berusaha menyeragamkan istilah yang telah ditawarkan; ini tentu saja tidaklah selalu menghasilkan istilah yang sama (seluruhnya atau sebagian) bagi semua anggota MABBIM, (5) secara terpisah, masing-masing pihak menerbitkan daftar istilah; dokumen itu kadangkala dilengkapi dengan kamus istilah yang terdiri dari istilah sasaran, definisi dalam bahasa sasaran dan istilah sumber. Bahasa.

1 Kini (dan sejak tahun 1998) Pusat Bahasa. Selanjutnya disebut sebagai Pusat

2 Sebagai sumber informasi lihat juga laman Pusat Bahasa (2008): http:// pusatbahasa. diknas.go.id/glosarium>.

3 Di sini, sebutan "Melayu" dimaksud dalam arti netral untuk menunjuk dua bahasa baku/resmi sekaligus, bahasa Indonesia dan bahasa Malaysia. Pihak Malaysia tidak menggunakan lagi istilah "Malaysia" untuk menyebut bahasa nasionalnya, melainkan "Melayu".

Dari tahun 1984 hingga awal tahun 2000-an. 


\subsection{INOVASI MORFOLOGIS}

Di lain tulisan, kami sudah sempat meneliti soal pemodernan kosa kata ilmiah dan teknis bahasa Indonesia, termasuk program kerja sama dalam rangka MABBIM dan keberhasilan implementasi peristilahan resmi di Indonesia (Samuel 2005). Di sini, kami ingin memfokuskan perhatian pada sebuah prosedur pembentukan istilah yang kami anggap sebagai salah satu batu ujian kebijakan pengembangan istilah yang diusahakan oleh lembaga peristilahan Indonesia sejak Orde Baru.

Untuk memenuhi keperluan beristilah, terminolog-terminolog Indonesia mengaplikasikan berbagai prosedur yang cukup beragam: pemungutan langsung atau tak langsung, afiksasi, pemajemukan, penggabungan kata, ${ }^{5}$ sintagmatisasi. Dalam kertas ini, kami akan menelaah prosedur afiksasi "kompleks", yaitu salah satu jenis afiksasi yang khas dan sengaja dikembangkan oleh kalangan terminologi resmi di Indonesia. Menurut kami, pilihan ini tidak menentang dasar-dasar dan dinamika sistem afiksasi bahasa Indonesia, sekalipun prosedur itu praktis tidak hidup di luar kalangan Pusat Bahasa. Afiks kompleks yang kami uraikan di sini adalah yang paling sering ditemukan dalam daftar dan kamus istilah Pusat Bahasa, yaitu ke-ter-K. DASAR-an (selanjutnya disingkat keter-/-an). Pertama kami akan mengkaji dasar dan jalan afiks tersebut: bagaimanakah ciri-cirinya? Kenapa perlu dibedakan dari kombinasi afiks lain? Kemudian kami akan menguji keberterimaannya dan bertanya sejauh mana suatu lembaga kebahasaan dapat memaksakan prosedur morfologi baru kepada masyarakat penutur. Sebagaimana akan kita lihat, afiksasi kompleks yang memanfaatkan dan mengembangkan kekayaan sistem afiksasi yang asli Indonesia, ternyata merupakan sejenis pungut terjemah dari bahasa Inggris, sebagai akibat pendekatan terminologi terjemahan yang mendominasi di Indonesia. Akhirnya, dua pertanyaan yang ingin kami tanyakan adalah: (1) dapatkah inovasi morfologis itu diterima oleh dua lembaga resmi kebahasaan Melayu lain, yaitu Dewan Bahasa dan Pustaka Malaysia dan Dewan Bahasa Brunei Darussalam? (2) Apakah artinya pilihan dan promosi afiksasi kompleks dalam konteks ideologis Orde Baru, mengingat berbagai prinsip Orde Baru yang mendasari usaha-usaha resmi di bidang kebahasaan dan peristilahan?

\subsection{KORPUS DAN SUMBER DATA}

Kajian ini berdasarkan 62 istilah berafiks keter--an yang kami kumpulkan dari

$5 \quad$ Penggabungan kata adalah prosedur di tengah jalan antara pemajemukan dan afiksasi. Istilah atau kata gabungan terdiri dari dua unsur, keduanya morfem terikat atau bebas, yang kemudian dapat menerima afiks apa saja juga. Morfem yang dipilih (dan secara terselubung dianjurkan) untuk digunakan dalam penggabungan kata biasanya berasal dari bahasa Jawa kuno atau bahasa Sanskerta. Di samping itu, kata gabungan yang dihasilkan sering merupakan hasil pemungutan terjemah istilah Inggris yang terdiri dari unsur "klasik" (Yunani dan Latin). Oleh karena itu, kami cenderung menganggap penggabungan kata sebagai padanan Indonesia sebuah prosedur yang cukup umum dalam bahasa-bahasa Eropa (Pr. composition savante) dan kami memilih untuk menamakannya "penggabungan klasik". 
Opus magnum para ahli terminologi Pusat Bahasa tahun 1980-an dan 1990-an, yaitu empat seri kamus ilmu dasar (matematika, fisika, kimia, dan biologi). Seri itu bertujuan memenuhi keperluan dalam beristilah bagi sistem pendidikan Indonesia hingga perguruan tinggi S1. Semua istilah kamus-kamus tersebut kemudian dimuat dalam empat Glosarium (lihat daftar pustaka), ${ }^{6}$ yang lebih tepat disebut sebagai daftar istilah Inggris-Indonesia saja. Kamus itu diusahakan dalam rangka kerja sama MABBIM, tetapi pihak Malaysia tidak menerima istilah berafiks kompleks itu. Sumber ini bersifat preskriptif dan sejumlah besar istilah yang terkandung di dalamnya merupakan ciptaan pakar ilmu dan ahli bahasa Pusat Bahasa, jadi jelas mencerminkan prinsip dan kecenderungan mereka sendiri.

Selain itu, untuk mengukur keberadaan kata dan istilah berafiks kompleks di luar karya lembaga resmi, kami menggunakan tiga sumber data yang lain. Kami memeriksa Labrousse (1984; komunikasi pribadi 2002) dan Stevens dan Schmidgall-Tellings (2004). Berbeda dengan kamus Pusat Bahasa (termasuk Kamus Besar Bahasa Indonesia, 2001), dua sumber leksikografi itu mencerminkan pemakaian bahasa yang hidup dan nyata di Indonesia masa kini. Semua kata yang terdapat di situ ditemukan di sejumlah sumber teks, seperti terbitan pers, karya sastra, laman web, dan lain-lain. Pangkalan data Prof. Labrousse (Paris) telah dimulai pada awal tahun 1970-an dan diterbitkan dalam bentuk kamus dwibahasa (Kamus Umum Indonesia-Perancis, Paris 1984). Sejak itu, Prof. Labrousse terus mengumpulkan istilah dalam rangka persiapan edisi kedua kamusnya. Edisi itu belum terbit, namun Prof. Labrousse bersedia menyampaikan daftar kata berafiks keter-/-an yang dikumpulkannya hingga tahun 2002. Kamus dwibahasa Stevens and Schmidgall-Tellings (2004) merupakan sumber tambahan yang sangat kaya tetapi tidak diperiksa secara sistematis. Selain itu, kami juga mencoba untuk menguji korpus kami dengan pencarian di internet (Februari 2008).

\section{AFIKS YANG BERKAITAN DENGAN AFIKSASI KOMPLEKS}

Bahasa Melayu mempunyai sistem afiksasi yang kaya yang merupakan inti morfologinya. Sistem yang terdiri dari sejumlah prefiks, sufiks, konfiks, dan infiks ini memungkinkan pembentukan serangkaian kata turunan berdasarkan kata dasar yang terdiri dari verba, nomina atau kelas kata lain, termasuk kata dasar yang dipungut dari bahasa asing. Berikut ini, beberapa afiks menarik perhatian kami.

\subsection{PREFIKS DAN KONFIKS PEMBENTUK VERBA TRANSITIF}

Afiks yang dimaksud adalah sufiks pembentuk verba -kan dan -i. Makna dan jalan afiks ini tidak perlu dirinci, cukup mengingatkan bahwa verba yang diturunkan ini selalu transitif dan menerima prefiks penanda pasif $d i-$,

6 Untuk mendapat daftar yang dianggap rinci dan lengkap dari kamus istilah bidang ilmu yang disusun dan diterbitkan oleh Pusat Bahasa, lihat Samuel 2001. Dua kamus istilah fisika seri kamus ilmu dasar dianalisis dalam Samuel 2005, Bab 11 dan 12. 
sebagaimana kata dasar verba transitif.

\subsection{PREFIKS PEMBENTUK VERBA TER-DASAR}

Khusus dalam kaitannya dengan verba transitif, menurut Alieva (1991: 193) afiks ter-mempunyai keistimewaan berikut:

[...] imbuhan tersebut selalu menyatakan dua makna gramatikal sekaligus, yaitu makna diatesis pasif dan makna resultatif, perfektif. Kedua makna ini dapat pula ditambahkan dengan makna ketiga, yaitu makna modalitas kemungkinan atau makna ketidaksengajaan, ketidaksenangan. Oleh karena bentukan berawalan terkurang terang dan kurang pasti dalam menyatakan makna gramatikal, ditambah pula bentukan tersebut dibangun bukan dari sembarang dasar verba transitif, maka kiranya awalan tersebut tak dapat kita anggap sebagai formatif kategori infleksi yang reguler.

Verba berafiks ter- dapat dibagi dalam tiga kelompok:

1.2.1 Ter-I: bermakna "keadaan sebagai hasil sebuah proses"; di sini tidak dipandang pelaku maupun modalitas proses, namun verba kelompok ini bermakna pasif-perfektif dan proses yang hasilnya dirujuk selalu dapat diungkapkan dengan bentuk di-DASAR :

$\begin{array}{llll}\text { batas } & \text { membatasi } & \text { terbatas } & =\text { dalam keadaan telah dibatasi } \\ \text { buka } & \text { membuka } & \text { terbuka } & =\text { dalam keadaan telah dibuka } \\ \text { jamin } & \text { menjamin } & \text { terjamin } & =\text { dalam keadaan telah dijamin } \\ \text { asing } & \text { mengasingkanterasing } & =\text { dalam keadaan telah diasingkan }\end{array}$

1.2.2 Ter-II: membentuk verba, baik transitif maupun non transitif (tertawa, termenung). Dengan verba subkelompok transitif, ter-II bermakna pasif dan perfektif, tetapi pelaku proses yang dirujuk sering tidak hadir. Maknanya yang utama berkaitan dengan modalitas: "proses terjadi atau dilakukan dengan tidak sengaja":

$\begin{array}{lll}\text { bakar membakar } & \text { terbakar } & =\text { tidak sengaja dibakar } \\ \text { makan (me)makan } & \text { termakan } & =\text { tidak sengaja dimakan } \\ \text { tabrak menabrak } & \text { tertabrak } & =\text { tidak sengaja ditabrak } \\ \text { luka melukai } & \text { terluka } & =\text { tidak sengaja dilukai }\end{array}$

1.2.3 Ter-III: bermakna perfektif dan pasif juga, ditambah dengan makna modal "kemampuan (pelaku) untuk melakukan sesuatu, mengerjakan sebuah proses". Apabila pelaku dihadirkan, biasanya diawali dengan preposisi oleh. Makna ini kadang-kadang dianggap terdapat pada kata yang diturunkan dari beberapa kata dasar saja (lihat, dengar, dapat ...). Dua ciri lain adalah (1) kata turunan dengan ter-III sering mempertahankan akhiran -kan atau $-i$ verba

7 Rupanya sufiks verba - $i$ memungkinkan modalitas «tidak sengaja» ini muncul pada sejumlah kata berafiks ter-. Periksa: terbasahi, terlampui, dan sebagainya. 
terkait (Alieva 1991: 192; lihat juga daftar contoh dalam Sneddon 1996: 116118), dan (2) prefiks ini terutama ditemukan dalam konstruksi negatif tidak/ tak ter- untuk menyatakan ketidakmungkinan atau ketidakmampuan: ${ }^{8}$
lihat melihat
(tak) terlihat
$=($ tak $)$ dapat dilihat
atas mengatasi
(tak) teratasi
$=($ tak) dapat diatasi
elak
mengelakkan
(tak) terelakkan
$=($ tak$)$ dapat dielakkan

Sebenarnya, pembedaan antara tiga makna ter- rancu juga sebab

banyak pula verba berawalan ter-yang dapat menyampaikan dua makna tersebut [ter-I dan ter-II], misalnya: terpadam bisa berarti: 1) tak sengaja dipadamkan, 2) selesai dipadamkan (makna perfek). Makna kemampuan atau kesanggupan yang jelas sekali pada beberapa verba transitif berawalan ter-, namun dalam verba intransitif tidak keluar sendiri; hanya dalam beberapa verba bermakna perfek (kompletif) makna tersebut kadang-kadang dirasakan sebagai makna sampingan: terhindar, tertidur, tersandar. (Alieva 1991: 141).

Catatan itu penting sekali karena sejumlah kata berafiks ter- yang bermakna ganda justru dimanfaatkan sebagai batu loncatan oleh terminolog Pusat Bahasa.

Terakhir, perlu ditambah juga bahwa awalan ter-mempunyai satu makna lagi, khusus untuk verba statis: «yang paling». Makna superlatif ini kurang relevan untuk kajian kami, namun bukannya sama sekali tidak hadir, maka selanjutnya dicatat ter- 0 .

\subsection{KONFIKS PEMBENTUK NOMINA KE-/-AN}

Konfiks ini terutama mengungkapkan keabstrakan (sifat, keadaan) yang berkaitan dengan kata dasar:

baik kebaikan

anggota keanggotaan

boleh kebolehan

\subsection{KOMBINASI AFIKS}

Di samping itu, sejumlah kata berafiks yang sudah mantap dapat diafiksasi lagi dalam berbagai kombinasi afiks. Kombinasi afiks bukan sesuatu yang jarang maupun baru, dan memungkinkan kita membentuk nomina atau verba:

$$
\begin{aligned}
& \text { kata dasar }_{1} \rightarrow \text { afiks }_{1}+\text { kata dasar }_{1} \rightarrow \\
&=\text { kata dasar }_{2} \text { afiks }_{2}+\left[\text { afiks }_{1}+\text { kata dasar }_{1}\right] \\
&=\text { afiks }_{2}+\left[\text { kata dasar }_{2}\right]
\end{aligned}
$$

8 Perlu ditambah juga bahwa bahasa Minangkabau mempunyai prefiks serupa: “The use of the prefix $t a$ - before a transitive verb to indicate ability is very productive in spoken Minangkabau, especially in negative sentences." (Susanto 1996 : 160; lihat juga Moussay 1995, II: 1109). 
Dengan kata lain, kombinasi afiks diterapkan pada kata-kata dasar berafiks yang sudah diterima sebagai bentuk polimorfemis yang otonom, kemudian dimanfaatkan sebagai dasar baru dan dapat diberi afiks lagi. Kombinasi afiks ini biasanya muncul secara spontan dan dapat disebut afiksasi ganda atau sekunder.

Dalam berbagai kasus, kata dasar semula tidak hidup lagi (lihat 2 di bawah ini) atau ikatannya dengan kata berafiks tidak terasa kuat lagi, sehingga kata berafiks patut dianggap sebagai bentuk monomorfemis oleh penutur awam (lihat 5). Berikut ini beberapa contoh:

\begin{tabular}{|c|c|c|}
\hline aksara & $\underline{\text { ber-aksara }}$ & KE-beraksara-AN \\
\hline 2. *aruh & peng-aruh & BER-pengaruh \\
\hline 3. hulu & peng-hulu & KE-penghulu-AN \\
\hline batas & ter-batas & KE-terbatas-AN \\
\hline $\begin{array}{l}\text { tawa } \\
\text { tuju }\end{array}$ & $\begin{array}{l}\text { tertawa MEnertawal, } \\
\text { tuju-an }\end{array}$ & $\begin{array}{l}\text { MEnertawaKAN } \\
\text { BER-tujuan, dan lain- }\end{array}$ \\
\hline
\end{tabular}

A. Teeuw (1998: 27-28) menggarisbawahi dinamika bahasa Indonesia masa kini yang memperluas pemakaian afiks yang tersedia, dan memunculkan potensialitas baru khususnya melalui kombinasi afiks:

Afiksasi ganda: kata-kata polimorfemik dapat kemudian dijadikan kata turunan baru, pada skala yang jauh lebih luas dari pada zaman dulu. Di samping itu, ini sering terjadi pada kata pungut terjemah. Kasus yang umum adalah: ber- dikombinasikan dengan nomina yang diturunkan dengan -an (...) [atau] ke-an (...) yang dikombinasikan dengan bermacam-macam kata polimorfemik.

Antara lain ia menyebut keterkejutan dan keterharuan. Demikian juga, Kridalaksana (1992: 75-76) mencatat tujuh kombinasi afiks: keber-/-an (keberhasilan), kese-/an (keseimbangan), keter-/-an (keterlibatan), pember-/-an (pemberlakuan), pemer-/-an (pemerolehan), penye-/-an (penyekutuan), perse-/-an (persemakmuran). ${ }^{9}$

\section{AFIKSASI KOMPLEKS}

\subsection{PRINSIP}

Apabila ditinjau sepintas lalu, afiksasi kompleks merupakan salah satu jenis kombinasi afiks di antara sekian yang lain. Sebenarnya, afiksasi kompleks berbeda dengan skema afiksasi sekunder dan prinsipnya mengikuti patokan lain:

(1) Para terminolog Pusat Bahasa menggunakan prosedur ini untuk membentuk neologisme yang diberi afiks sekunder, tanpa harus melalui

9 Tiga kombinasi pertama disebut juga oleh Pusat Bahasa dalam "paradigma bentuk berkonfiks ke-/-an" (keber-/-an: kebermaknaan, keter-/-an: keterpurukan, dan kese-/-an: keseragaman), yang dapat dimanfaatkan untuk memenuhi keperluan pemerlengkapan istilah (Pedoman Umum 2004: 26). 
tahap antara otonomi kata yang berafiks primer. Agar mengerti arti istilah berafiks kompleks, pemakai istilah terpaksa merujuk pada sebuah bentuk berafiks primer yang ternyata tidak hidup (tidak ada dalam arti yang dimaksud oleh terminolog atau sama sekali tidak ada), tidak otonom atau kurang mantap (dengan frekuensi kemunculan kata yang rendah). Kebanyakan hanya ditemukan dalam kamus-kamus istilah (preskriptif) Pusat Bahasa.

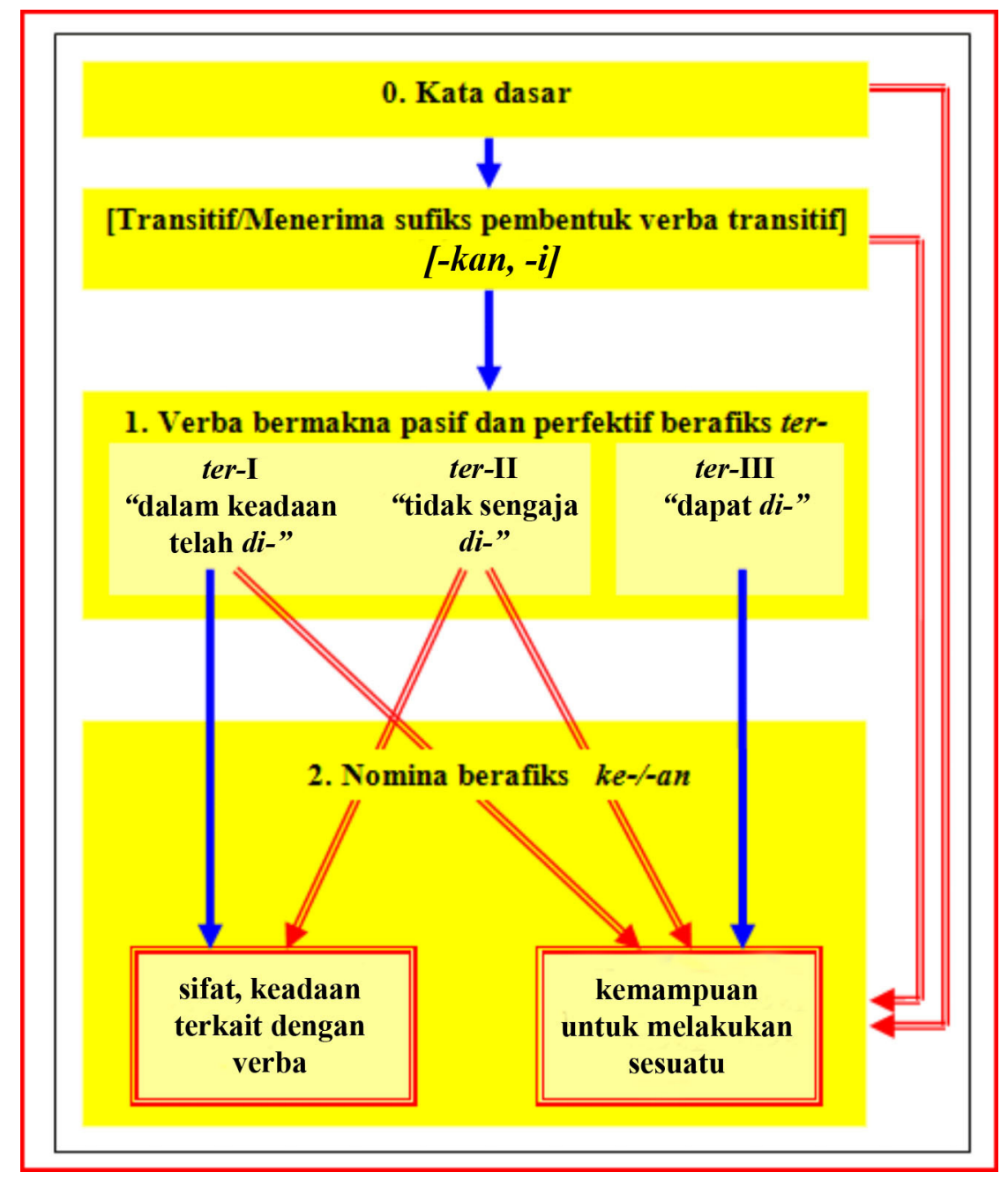

Bagan 1

(2) Bentuk berafiks kompleks adalah konstruksi yang dikembangkan secara sadar dan sengaja, bukan neologisme spontan, justru karena merupakan hasil lompatan semantis atau morfologis. Terkadang pemakaian afiks kompleks cukup rumit, sehingga menimbulkan keragu-raguan di kalangan pakar Pusat Bahasa sendiri (lihat contoh supraconductivity pada 2.4.2). Hampir semua istilah berafiks kompleks rekaan Pusat Bahasa menggunakan dua afiks di atas ini, ter-dan ke-/-an, dan mengikuti prosedur 
yang digambarkan pada bagan alir seperti Bagan 1.

Bentuk yang kami maksud di sini dapat diturunkan dari kata dasar jenis apa saja (nomina: arah, kutub, verba dinamis: hantar, cerna, verba statis: urai, campur) dan kata dasar hampir selalu mempunyai turunan verba transitif dengan afiks $m e N-$, meN-/-kan, meN-/-i. ${ }^{10}$ Jenis batang panah membedakan antara dua jenis kombinasi afiks:

$\longrightarrow$ Panah ini mengikuti skema pembentukan kata/istilah berafiks ganda (sekunder). Bentuk-bentuk ini dapat direalisasikan secara spontan oleh penutur awam.

$\longrightarrow$ Panah ini menunjuk pada jalan pembentukan istilah berafiks kompleks, kebanyakan atau semua rekaan Pusat Bahasa.

Berikut ini beberapa contoh yang diambil dari korpus kami untuk melengkapi bagan alir. Akan tetapi sebelumnya perlu kami tekankan bahwa tidak selalu mudah untuk menentukan jenis afiksasi yang diaktifkan (sekunder atau kompleks) dan untuk memilah antara berbagai afiks kompleks. Sebabnya ialah beberapa kata dasar menerima prefiks ter- dengan dua makna, misalnya:

$\begin{array}{lll}\text { ? andal } & \text { terandal } & \text { ter-0 dan ter-III } \\ \text { bagi } & \text { terbagi } & \text { ter-I dan ter-III } \\ \text { balik } & \text { terbalik } & \text { ter-I atau ter-II } \\ \text { pancar } & \text { terpancar dan terpancarkan } & \text { ter-II dan ter-I } \\ \text { ? waris } & \text { terwarisidan terwariskan } & \text { ter-I dan ter-III, }\end{array}$

sedangkan pada kata lain, makna prefiks ter- bergantung pada keberadaan akhiran -kan. Memang, beberapa kasus menghadapkan ter-I dan ter-III-/-kan, di mana adanya akhiran -kan merupakan syarat wajib untuk menambahkan nilai modal "yang dapat di-" pada kata berafiks ter-I. Fenomena ini tampaknya lepas dari kelas kata dasar yang bersangkutan, misalnya:

$\begin{array}{lll}\begin{array}{l}\text { ? balik } \\ \text { belah }\end{array} & \text { terbalik } & \text { terbelah } \\ \text { jumlah } & \text { terjumlah } & \underline{\text { terbelahkan }} \\ \text { larut } & \text { terlarut } & \text { terterjumlahkan } \\ \text { mampat } & \underline{\text { termampat }} & \text { terlarutkan } \\ \text { tempa } & \text { tertempa } & \underline{\text { termampatkan }} \\ \end{array}$

Kata/istilah berprefiks ter- (I, II atau III) yang tidak termuat dalam kamus yang kami rujuk, biasanya ada di internet, dengan frekuensi yang tidak selalu rendah. Dalam hal ini, keberterimaan kata bisa saja kita anggap teruji oleh penutur asli, walaupun sulit untuk menentukan apakah pemakaian ini benarbenar mewakili kebiasaan masyarakat penutur atau tidak.

10 Kamus yang kami periksa tidak mengenal verba transitif yang diturunkan dari diagonal, diferensial, dan integral. Namun, bagi pakar matematika mengintegralkan cukup lazim dan mendiferensialkan bukan istilah langka. 


\subsection{KATA/ISTILAH BERAFIKS SEKUNDER KETER-/-AN (29 ISTILAH)}

Berikut ini beberapa contoh yang kami peroleh dari Glosarium istilah terbitan Pusat Bahasa.

\subsubsection{Dengan makna ter-I}

$\begin{array}{ll}\text { arah } \rightarrow \text { mengarahkan } & \rightarrow \text { terarah } \rightarrow \text { keterarahan "directivity" } \\ \text { batas } \rightarrow \text { membatasi } & \rightarrow \text { terbatas } \rightarrow \text { keterbatasan "boundedness" } \\ \text { campur } \rightarrow \text { mencampurkan } & \rightarrow \text { tercampur } \rightarrow \text { ketercampuran "mixedness" } \\ \text { gantung } \rightarrow \text { menggantung } & \rightarrow \text { tergantung } \rightarrow \text { ketergantungan, "dependence" }\end{array}$

\subsubsection{Dengan makna ter-II}

Korpus kami mengandung tiga istilah yang (dapat) diturunkan melalui ter-II (keterbalikan, keterimpitan, dan keterpancaran), tetapi tidak satu pun mempertahankan unsur makna tersebut.

\subsubsection{Dengan makna ter-III}

dengar $\rightarrow$ mendengar $\rightarrow$ terdengar $\rightarrow$ keterdengaran "audibility" beda $\rightarrow$ membedakan $\rightarrow$ terbedakan $\rightarrow$ keterbedaan, "distinguishability" laksana $\rightarrow$ melaksanakan $\rightarrow$ terlaksana $\rightarrow$ keterlaksanaan "feasibility" jangkau $\rightarrow$ menjangkau $\rightarrow$ terjangkau $\rightarrow$ keterjangkauan "reachability"

\subsubsection{Dengan makna ganda}

tempa $\rightarrow$ tertempa (I) tertempakan (III) $\rightarrow$ ketertempaan "malleability"

belah $\rightarrow$ terbelah (I) terbelahkan (III) $\rightarrow$ keterbelahan "fissionability"

bagi $\rightarrow$ terbagi (I) terbagi (III) $\rightarrow$ keterbagian "divisibility"

jumlah $\rightarrow$ terjumlah (I) terjumlahkan (III) $\rightarrow$ keterjumlahan "summability"

\subsection{ISTILAH BERAFIKS KOMPLEKS KETER-/-AN}

Di sini, bukan makna ter-asli tetapi makna ter- baru yang diaktifkan untuk menciptakan neologisme melalui afiksasi ke-/-an. Atau malah kata dasar semula tidak kenal prefiks ter-, apa pun maknanya. Proses pembentukan istilah melibatkan lompatan semantis (2.3.1) atau morfologis (2.3.2).

\subsubsection{Dengan lompatan semantis (22 istilah)}

Istilah berafiks di bawah ini dibentuk berdasarkan kata dasar yang menerima prefiks ter-I atau ter-II, tetapi kombinasi afiks keter-/an memunculkan makna ter-III yang tidak atau jarang diterima:

(a) Pergeseran makna ter-I $\rightarrow$ ke-ter-III-/-an

kutub $\rightarrow$ mengutubkan $\rightarrow$ terkutub $\rightarrow$ keterkutuban "polarizability" identifikasi $\rightarrow$ mengidentifikasi $\rightarrow$ teridentifikasi $\rightarrow$ keteridentifikasian "identificability"

(b) Pergeseran makna ter-II $\rightarrow$ ke-ter-III-/-an atau ter-II $\rightarrow$ ke-ter-I-/-an: dari tiga kata berafiks ter-II, dua mengikuti pola paling umum dan bergeser ke makna «mampu di-»: 
balik $\rightarrow$ membalikkan $\rightarrow$ terbalik $\rightarrow$ keterbalikan"reversibility" pancar $\rightarrow$ memancarkan $\rightarrow$ terpancar $\rightarrow$ keterpancaran "emissivity" Yang ketiga bergeser ke ter-I, tetapi istilah ini cukup meragukan: ? (h)impit $\rightarrow$ meng $(h)$ impitkan $\rightarrow$ ter(h)impit $\rightarrow$ keter $(h)$ impitan "coincidence"

2.3.2 Dengan lompatan morfologis (11 istilah)

Penurunan kata dasar melompati tahap afiksasi dengan ter-:

(a) Tiga kata dasar yang dimanfaatkan di sini hanya menerima afiks superlatif ter-0 ("yang paling") dan pantas disatukan dengan kelompok ini:
putih $\rightarrow$ [terputih]
akrab $\rightarrow$ [terakrab]
$\rightarrow$ keterputihan "bleachibility"
basah
$\rightarrow$ [terbasah(i)]
$\rightarrow$ keterakraban "sociability"
$\rightarrow$ keterbasahan "wettability"

Kamus umum yang tersedia tidak mengenal afiks ter-/-kan atau ter$/-i$ pada kata dasar di atas. Pencarian di internet membawa beberapa bentuk berafiks, tetapi dengan frekuensi yang sangat rendah (di bawah 50 halaman), kecuali terbasahi $(1.400)^{11}$.

(b) Istilah di bawah ini tidak diturunkan dengan prefiks ter- (termasuk ter-0) menurut kamus umum yang dirujuk. Mesin penelusuran di internet berhasil menimba beberapa kata berafiks ter- atau ter-/-kan, namun tetap dalam jumlah yang kami anggap kurang mewakili. Maka kami memandang istilah yang berikut sebagai istilah kompleks morfologis:

\begin{tabular}{|c|c|c|}
\hline $\begin{array}{l}\text { diferensia } \\
\text { diagonal } \\
\text { tetas } \\
\text { hidup }^{12}\end{array}$ & $\begin{array}{l}\rightarrow \text { keterditerensialan } \\
\rightarrow \text { keterdiagonala } \\
\rightarrow \text { ketertetasan } \\
\rightarrow \text { keterhidupan }\end{array}$ & $\begin{array}{l}\text { "diagonalizability" } \\
\text { "hatchability" } \\
\text { "viability" }\end{array}$ \\
\hline
\end{tabular}

2.3.3 Dengan makna ganda: afiks sekunder dan afiks kompleks.

Kata dasar di bawah ini dimanfaatkan untuk membentuk dua istilah dengan makna yang berbeda, salah satu berafiks sekunder, yang satunya berafiks kompleks dengan lompatan semantis:

$\begin{array}{rlll}\text { campur } & \rightarrow \text { tercampur } & \rightarrow \text { ketercampuran }_{\mathrm{I}} & \text { "mixedness" } \\ & \rightarrow \text { tercampurkan } & \rightarrow \text { ketercampuran }_{\mathrm{III}} & \text { "miscibility" } \\ \text { hubung } & \rightarrow \text { terhubung } & \rightarrow \text { keterhubungan } & \text { "connectedness" } \\ & \rightarrow \text { terhubungkan } & \rightarrow \text { keterhubungan } & \text { "connectivity" } \\ \text { ?larai } & \rightarrow \text { terlarai } & \rightarrow \text { keterlaraian }_{\mathrm{I}} & \text { "reflectance" } \\ & \rightarrow \text { terlaraikan } & \rightarrow \text { keterlaraian } & \text { III } \\ \text { pantul } & \rightarrow \text { terpanta] }]^{\text {"resolving [power]" }} & \rightarrow \text { keterpantulan }_{\mathrm{I}} & \text { "reflectance" } \\ & \rightarrow \text { terpantulkan } & \rightarrow \text { keterpantulan } & \text { "reflectivity" }\end{array}$

11 Rupanya dengan makna "tidak sengaja dibasahi".

12 Stevens dan Schmidgall-Tellings (2004) mencatat: "terhidup keterhidupan viability" tanpa padanan untuk kata terhidup. 


\subsection{PERKEMBANGAN LAIN}

Akhirnya, afiks kompleks dimanfaatkan lagi untuk menurunkan istilah yang terdiri dari berbagai unsur, dalam hal ini morfem terikat atau tidak.

\subsubsection{Dengan negasi}

Istilah berafiks ter-diawali negasi tak atau tidak kemudian diberi afiks keter/-an:

ketakterandalan ("unreliability") ketakterbedaan ("undistinguishability") ${ }^{13}$ ketakterhidupan ("unviability") ketakterhinggaan ("unfiniteness") ketaktereduksian ("irreducibility")

Pemakaian negasi sebagai unsur gabungan dalam pembentukan istilah memang fenomena yang lama ${ }^{14}$ dan tidak langka. Belum lagi, sebagaimana telah kita lihat banyak kata berawalan ter-III biasanya digunakan dengan negasi untuk menyatakan "tidak mampu". Di samping istilah di atas, kami menemukan juga:

takterarah ("undirectional") takterbalikkan ("irreversible") takterbatas ("undeterminate") takterbedakan ("undistinguishable")

\subsubsection{Dengan unsur gabungan}

Sejumlah kecil istilah berafiks keter-/-an dikombinasikan dengan unsur gabungan sebagai morfem terikat (piro) atau dengan morfem bebas dalam kata majemuk (lewat):

keterkutubantensoran ("tensorpolarizability")

keterlewatlarutan ("supersolubility")

mikroketerbalikan ("microreversibility")

adiketerhantaran ("supraconductivity")

fotoketerhantaran ("photoconductivity")

magnetoketerhantaran ("magnetoconductivity")

piroketerhantaran ("pyroconductivity")

Semua istilah di atas ini dihasilkan oleh kelompok kerja fisikawan, di bawah pimpinan Liek Wilardjo, salah satu pakar (dan ahli terminologi) yang paling konsisten menerapkan prosedur afiksasi sekunder dan kompleks. Namun, istilah yang terdiri dari empat unsur yang berbeda (kata dasar, afiks primer, afiks sekunder, unsur tambahan) tidaklah mudah dirakit, dan terminolog Pusat Bahasa rupanya pusing memikirkan bentuk yang paling tepat untuk mengungkapkan "supraconductivity", misalnya. Setelah memilih unsur Sanskerta adi untuk menerjemahkan unsur Latin "supra", secara berturut- 
turut mereka menawarkan adiketerhantaran ${ }^{15}(1990)$, keteradihantaran ${ }^{16}(1993)$, keadihantaran ${ }^{17}$ (1993) dan akhirnya adihantaran (1996) ${ }^{18}$. Ternyata, permainan dengan afiksasi kompleks mempunyai keterbatasannya sendiri.

\subsection{MENGUKUR IMPLEMENTASI DAN KEBERTERIMAAN ISTILAH}

Pada umumnya, kombinasi morfem keter-/-an bukan sesuatu yang aneh bagi masyarakat penutur di Indonesia, tetapi kombinasi tersebut jarang dikenal dengan makna yang diandalkan oleh Pusat Bahasa ("kemampuan"). Labrousse (2002) mencantumkan tidak kurang dari 110 kata berafiks keter-/-an, namun hanya 14 yang di antaranya terdapat dalam Glosarium (12 dengan makna yang sama) dan semua sebagai kata berafiks sekunder kecuali tiga (keterbalikan, keterlarutan, dan ketermampatan). Stevens dan Schmidgall-Tellings (2004) mencatat 23 dari 61 istilah korpus kami, dengan enam kata berafiks kompleks saja (keterdandalan, ketercacahan, keterhambatan, keterhidupan, keterserapan, keteruraian). Selain itu, sebuah daftar kata menurut frekuensi pemakaiannya dalam bahasa Indonesia (Muhadjir 1996) ${ }_{1}^{19}$ meresensi $34 \mathrm{kata} /$ istilah berafiks keter-/-an. Delapan di antaranya juga terdapat dalam Glosarium Pusat Bahasa, tetapi hanya satu mengandung makna "kemampuan" (keterbelahan) dan tidak satu pun dapat dianalisis sebagai istilah berafiks kompleks. ${ }^{20}$

Biar bagaimana pun juga, sampai beberapa tahun lalu kebanyakan terminolog dan pakar di Pusat Bahasa tidak memandang perlu untuk menaruh perhatian yang besar pada soal kelaziman istilah dan keberterimaan ciptaan mereka. Oleh karena mereka bekerja dalam perspektif preskriptif dan berusaha untuk mengubah kebiasaan beristilah, maka tingkat keberterimaan istilah bukan alasan utama untuk mempromosikan atau untuk menolak sebuah istilah baru. Sebagaimana banyak terminolog di Eropa sampai akhir tahun 1980-an, mereka anggap ciptaan lembaga peristilahan resmi dapat saja diterima oleh masyarakat asalkan ciptaan itu memenuhi keperluan "teknis" para pemakai dan berhasil disebarluaskan secara memuaskan. Di situ terdapat dua kelemahan utama Pusat Bahasa sepanjang zaman Orde Baru, yaitu kurang memperhatikan istilah yang muncul secara spontan dan hidup di tengah masyarakat penutur, dan kurang berupaya untuk mengimplementasikan istilah baru.

Kegagalan implementasi istilah jelas terlihat dalam sejumlah buku sekolah yang dapat kami periksa. ${ }^{21}$ Buku itu jarang menggunakan ciptaan resmi Pusat

15 Penggabungan klasik pada istilah berafiks kompleks. Diberi sebagai padanan Indonesia istilah Inggris dalam Ismail dan Hussin (1990).

16 Afiksasi kompleks (keter-/-an) pada kata gabungan klasik (adi + hantar), dalam Prawirosusanto dkk. (1993).

17 Kata gabungan klasik (adi +hantar) berkonfiks (ke-/-an) dalam Wilardjo dan Murniah (1995).

Kata gabungan klasik (adi +hantar) bersufiks (-an) dalam Yohannes dkk. (1996).

Kata daftar itu dikumpulkan berdasarkan 52 edisi harian Kompas tahun 1994.

20 Untuk bahan bandingan, kami telah mencari semua bentuk yang dimulai dengan keter* melalui mesin penelusur exalead. fr. Dari sekitar 280 bentuk yang berhasil dikumpulkan, sekali lagi hanya sebagian kecil dapat dianggap sebagai kata atau istilah berafiks kompleks.

${ }_{21}$ Kami juga sempat meneliti peristilahan bidang ilmu logam dan metalurgi, dan 
Bahasa dan sama sekali tidak memakai istilah berafiks kompleks (lihat Samuel 2005: Bab 12, tentang implementasi sejumlah istilah termodinamika). Ternyata, penulis buku pelajaran lebih suka memanfaatkan istilah yang umum tanpa memandang asal dan "keabsahan"-nya, atau pun tetap mempertahankan istilah lama yang dihasilkan oleh Komisi Istilah pada tahun 1950-an dan 1960an, dan lama-lama berakar sehingga masih tetap digunakan.

\subsubsection{Pemakaian istilah di luar kalangan Pusat Bahasa}

Kami telah mempergunakan mesin penelusur Google untuk memeriksa keberadaan ciptaan Pusat Bahasa di internet dan frekuensi pemakaiannya, dengan harapan pencarian halaman yang memuat istilah korpus kami (atau, paling sedikit, bentuk yang sama) dapat melengkapi gambaran yang kita dapati dari tiga sumber di atas. Pemakaian internet sebagai sumber dan mesin penelusur untuk penelitian leksikografi atau terminologi kurang meyakinkan dan hasilnya tidak selalu masuk akal. Penerapan kriteria pencarian yang sama, apabila diulang pada saat yang berbeda akan membawa hasil yang kadangkala jauh berbeda. Di samping itu, sejumlah teks yang diperoleh dari internet kurang mewakili, sedangkan kondisi produksi teks itu sulit ditentukan. Terakhir, frekuensi kemunculan kata tidak dapat diukur dengan pasti. Namun, kami anggap pencarian di internet paling sedikit sanggup memberi kesan yang menarik dan berguna.

Dari segi frekuensi kemunculan (lihat jumlah halaman yang tercantum dalam tabel terlampir), korpus kami dapat dipilah sebagai berikut:

- kata yang termasuk kosa kata umum atau istilah yang dapat dikatakan sudah lazim (dengan minimal ribuan halaman); empat belas bentuk, dengan tiga di antaranya yang berafiks kompleks (keterandalan, keterbalikan, keterserapan);

- istilah yang rupanya sudah berterima, walupun frekuensinya relatif rendah (ratusan halaman): empat bentuk, tetapi hanya satu istilah dengan afiks kompleks (keterhambatan);

- istilah langka yang sama sekali atau hampir tidak dikenal (di bawah 100 halaman), yaitu 43 bentuk dan 28 istilah berafiks kompleks. Di sini, perlu dicatat juga bahwa di samping berbagai universitas, dua lama web sering memunculkan istilah berafiks kompleks langka, yaitu Wikipedia Indonesia dan sebuah kamus on-line. ${ }^{22}$

\subsubsection{Istilah alternatif}

Terminolog Pusat Bahasa sendiri menyadari bahwa istilah ciptaan mereka akan menghadapi saingan istilah lain yang sudah mantap. Oleh karena itu, mereka ternyata menawarkan sejumlah istilah alternatif yang hampir semua

mengukur pemakaian istilah Pusat Bahasa. Dari penelitian itu kami menarik kesimpulan yang sama (Samuel akan terbit b.).

22 Institut Teknologi Bandung, Universitas Sumatra Utara, dan Universitas Kristen Petra di Surabaya. Alamat kamus on-line yang kami maksud adalah: http:/ /www.babylon.com/ dictionary/41936/.: Mas_NDon-Indonesian-to-English-Dictionary/. 
dipungut langsung dari bahasa Inggris:

absoptivitas (keterserapan)

difusivitas (keterbauran)

direktivitas (keterarahan)

emisivitas (keterpancaran)

helisitas (keterpilinan)

kelarutan (keterlarutan)

kompresibilitas (ketermampatan) konduktans (keterhantaran)

konduktivitas (keterhantaran)

misibilitas (ketercampuran)

polarisabilitas (keterkutuban)

reflektans (keterpantulan,)

reflektivitas (keterpantulan ${ }_{\mathrm{III}}$ )

resistivitas (keterhambatan)

Apabila dilihat dari segi morfologi, baik konfiks keter-/-an maupun sufiks -ivitas atau -bilitas merupakan terjemahan dari sufiks Inggris -bility atau -ivity. Namun, kami perkirakan bahwa keberterimaan istilah bersufiks -itas lebih tinggi. Pertama, sufiks itu digunakan dalam bahasa Indonesia sejak tahun 1950-an dan semakin produktif (eneriisitas, genialitas, komunitas, (mono)loyalitas, moralitas, otosentrisitas, dan rutinitas); jadi, berbeda dengan afiks kompleks keter--an, sufiks -itas sudah dikenal melalui sebuah paradigma yang koheren. Kedua, pemakai istilah cenderung mengutamakan ketransparanan sebuah istilah pungutan terhadap bentuknya yang asli dalam bahasa sumber. Dalam hal ini -itas jelas lebih transparan dari pada keter-/-an.

\section{AFIKSASI KOMPLEKS SEBAGAI PUNGUT TERJEMAH}

\subsection{BAHASA INGGRIS DAN BAHASA-BAHASA "KLASIK" EROPA}

Secara formal, afiksasi kompleks tidak bertentangan dengan jalan morfologi Indonesia, tetapi sekali lagi prosedur ini tidak digunakan secara spontan oleh penutur asli yang awam. Penutur awam yang terdidik pun sering sulit mengidentifikasi makna istilah berafiks kompleks atau memberi keterangan yang memuaskan. Istilah berafiks kompleks yang merupakan perkembangan dari kata berafiks ter-I akan dikaitkan dengan maknanya yang asli dan lazim, tanpa menambah makna modal yang terkandung dalam ter-III. Pembandingan antara istilah Indonesia dengan istilah sumber dalam bahasa Inggris menunjukkan bahwa di sini terminolog Pusat Bahasa menerapkan pola sejenis pungut terjemah berafiks:

$$
\begin{aligned}
& \text { [bagi] membagi terbagi keterbagian } \\
& \text { to divide divisible divisibility } \\
& \text { ter-III } \leftrightarrow \text {-ible ke-/-an } \leftrightarrow-i \text { ty }
\end{aligned}
$$

di mana sufiks adjektiva -ible dan sufiks nomina -ity (keduanya Inggris dan berasal dari bahasa Latin) dikaitkan dengan prefiks ter-III dan konfiks keter/-an. Pola yang sama diaplikasikan pada contoh Bagan 2.

Pemakaian pemungutan terjemah adalah sesuatu yang wajar dalam konteks terminologi Indonesia, yaitu terminologi terjemahan asing (Inggris) > Indonesia. Pusat Bahasa sering memanfaatkan prinsip pemungutan terjemah, dengan berbagai prosedur : pungut terjemah harfiah ("electron gun" > senapang elektron), pungut terjemah transposisi ("avalanche diode" > diode longsoran), atau pungut terjemah terselubung melalui 
penggabungan morfem ("impurity" > takmurnian). ${ }^{23}$ Jadi pemungutan terjemah berafiks (kompleks atau tidak) hanya satu di antara sekian prosedur pembentukan istilah. Prosedur ini barangkali cukup mempesona di mata promotornya, karena memiliki beberapa keunggulan, antara lain:

(1) menjamin (atau diharapkan menjamin) ketransparanan makna istilah Inggris > Indonesia; ${ }^{24}$

(2) memungkinkan penyusunan seri istilah bersistem, misalnya:

larut $\rightarrow$ melarut(kan) $\rightarrow$ pelarut dan: $\rightarrow$ pelarutan

larut $\rightarrow$ dilarut(kan) $\rightarrow$ linarut dan: $\rightarrow$ terlarut $\rightarrow$ keterlarutan

(3) dapat diterapkan secara luas untuk menjadikan produktif sebuah paradigma afiks baru (keter-/-an dan -itas);

(4) mereproduksi sebuah struktur asing yang prestisius (Inggris dan bahasabahasa Eropa klasik) dengan tetap menjaga keindonesiaan bentuk istilah yang dihasilkan.

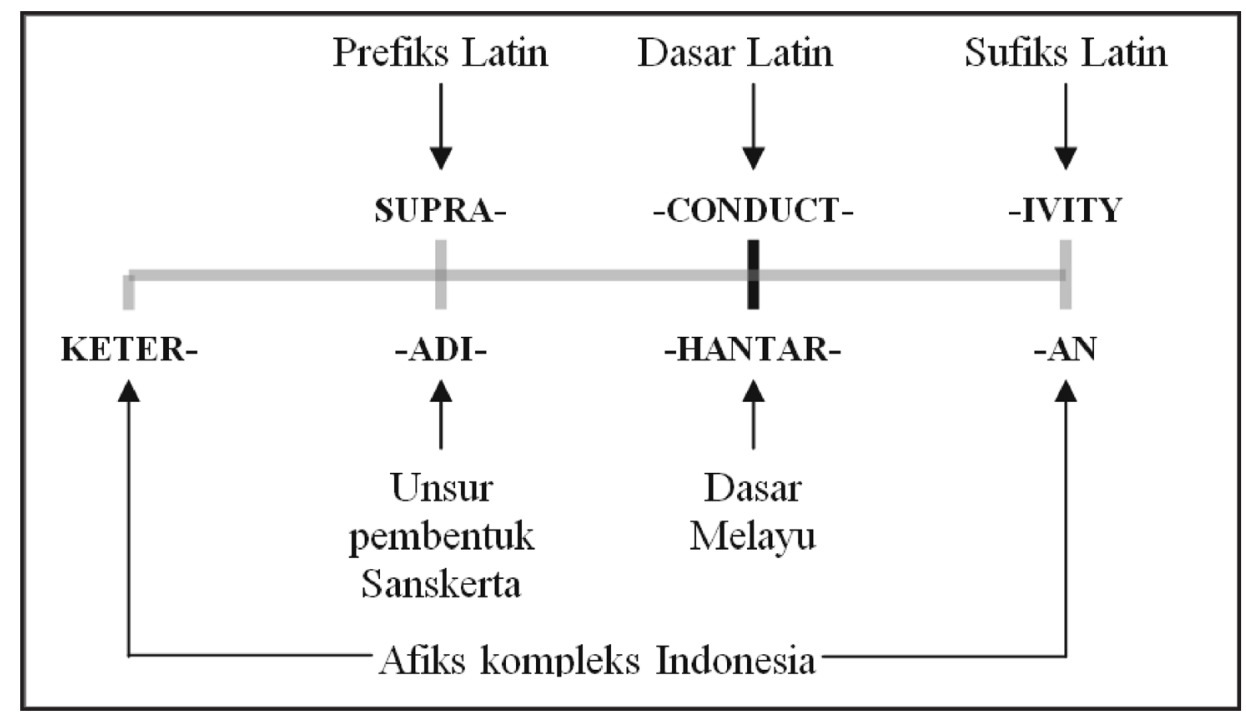

Bagan 2

Pada hemat kami, jenis konstruksi afiks kompleks diandalkan oleh terminolog Pusat Bahasa, justru sebagai pemungutan terjemah, sebagaimana terbukti dengan penolakan istilah alternatif yang bukan pungut terjemah (keterhantaran vs. BI kehantaran atau BM kerintangan).

\subsection{CATATAN DIAKRONIS}

Selera untuk menggunakan istilah pungut terjemah bukan fenomena yang langka di dunia terminologi, juga bukan suatu hal yang baru bagi terminolog

23 Semua contoh diambil dari Samuel 2005: Bab 11.

24 Analisis terminologi perlakuan panas logam menunjukkan bahwa pemungutan semantis belum tentu menjamin ketransparanan makna dan dapat menghambat pengertian, bahkan oleh pakar atau praktisi (Samuel akan terbit a. dan b.). 
Indonesia, termasuk di kalangan terminologi resmi. Kecenderungan yang sama sudah digemari lima puluh tahun silam dengan situasi sosiolinguistik yang tidak jauh berbeda dengan sekarang, sekalipun waktu itu kebutuhan beristilah lebih besar dan lebih mendesak. Selama kurang lebih dua puluh tahun (1947-1966), Komisi Istilah yang diserahi tugas pengembangan istilah menerapkan terminologi terjemahan juga, tetapi yang bersumber pada teks dan bahasa Belanda, bukan bahasa Inggris. Ini mengakibatkan pemakaian prosedur pembentukan istilah Indonesia yang mengikuti contoh lain, karena ciptaan Komisi Istilah sering dipungut atau diterjemahkan secara harfiah dari bahasa Belanda.

Berbeda dengan bahasa Inggris - bahasa rumpun Germania yang paling terpengaruh oleh bahasa Latin (melalui bahasa Prancis) -, bahasa Belanda banyak menggunakan pemajemukan kata. Oleh karena itu, sering terdapat istilah majemuk dalam daftar istilah yang disusun oleh Komisi Istilah. Setelah 1957, secara berangsur-angsur bahasa Belanda sebagai bahasa rujukan mulai diganti dengan bahasa Inggris, tetapi istilah-istilah lama dan prosedur lama tetap saja digunakan sampai didirikannya cikal bakal MABBIM dan Pusat Bahasa, pada awal tahun 1970-an. Berikut ini contoh dua istilah untuk menyebut konsep <conductivity>, yaitu kemampuan suatu benda untuk menghantarkan listrik, getaran-getaran tertentu, dan panas. Kedua-duanya merupakan pungut terjemah tetapi sangat berbeda dari segi morfologi:

Komisi Istilah (tahun 1950-an)

Bel. "geleidingsvermogen" $\rightarrow$ BI daya-hantar

Pusat Bahasa (sejak tahun 1970-an)

Ing. "conductivity"

$\rightarrow$ BI keterhantaran

Kini, Pusat Bahasa praktis tidak menciptakan lagi istilah majemuk seperti itu, ${ }^{25}$ tetapi istilah lama masih sering terpakai, barangkali karena dapat langsung dimengerti tanpa dianalisis dan dibedah terlebih dahulu. Namun, peralihan dari pola lama ke pola baru memerlukan beberapa tahun dan sampai pertengahan tahun 1980-an, prosedur afiksasi kompleks belum mantap. Sebuah kamus fisika yang disusun oleh pakar Pusat Bahasa waktu itu (Johannes dkk. 1984), masih mencantumkan pasangan istilah seperti:

$\begin{array}{ll}\text { "conductivity" } & \begin{array}{l}\text { kehantaran } \\ \text { "he)pilinan }\end{array} \\ \text { "emicity" } & \text { kepancaran } \\ \text { "reflectiviy" } & \begin{array}{l}\text { kepantulan } \\ \text { "resistivity" }\end{array} \\ \text { kehambatan } \\ \text { Di samping: } & \\ \text { "compressibility" } & \text { ketermampatan } \\ \text { "polarizability" } & \text { keterkutuban }\end{array}$

3.3 Kembali Ke MABBIM: PILIHAN MALAYSIA

Menarik juga untuk membandingkan pilihan Pusat Bahasa dengan

25 Namun, jumlah sintagma terminologis semakin besar. 
pilihan mitra kerjanya di seberang Selat Malaka, Dewan Bahasa. Memang, penyelarasan istilah antara anggota MABBIM bersifat sebagian (lihat Samuel 2005: Bab 11, untuk peristilahan elektromagnetika), belum lagi sampai awal tahun 2000-an pekerjaan bersama itu hanya menyangkut soal bentuk istilah, tanpa memandang definisi konsep yang dirujuk. Pemeriksaan berbagai "kamus istilah" (Indonesia) dan "glosari" (Malaysia) menghasilkan sejumlah pasangan Indonesia/Malaysia dan membuktikan dengan jelas, bahwa masingmasing pihak mengandalkan prosedur pembentukan istilah yang berbeda untuk menerjemahkan sufiks Ing. "-bility" / "-ivity":

$\begin{array}{lll}\text { Inggris } & \text { Indonesia26 } & \text { Malaysia } \\ \text { "conductivity" } & \text { keterhantaran } & \text { kekonduksian } \\ \text { "drawability" } & ? & \text { kebolehhelaan } \\ \text { "extrudability" } & ? & \text { kebolehsempritan } \\ \text { "fissibility" } & \text { keterbelahan? } & \text { kebolehbelahan } \\ \text { "floatability" } & ? & \text { kebolehapungan } \\ \text { "grindability" } & ? & \text { kebolehkisaran } \\ \text { "malleability" } & \text { ketertempaan } & \text { kebolehtempaan } \\ \text { "resistivity" } & \text { keterhambatan } & \text { kerintangan } \\ \text { "washability" } & \text { ketercucian } & \text { kebolehcucian } \\ \text { "wettability" } & \text { keterbasahan } & \text { kebolehbasahan } \\ \text { "workability" } & ? & \text { kebolehkerjaan }\end{array}$

Ciri paling menonjol daftar istilah Malaysia ini adalah kombinasi dua prosedur pembentukan kata yang umum dalam bahasa Melayu, yaitu afiksasi tunggal (ke-/-an) dan pemajemukan (boleh +). Secara intuisi, bentuk seperti itu lebih mudah diserap oleh penutur asli dari pada istilah berafiks kompleks, karena langsung menampakkan dua komponen dari konsep yang terungkap: kemampuan dan sifat abstrak, sedangkan afiks kompleks pada dasarnya tetap mengandung ambiguitas yang terdapat dalam prefiks ter-. Di samping itu kita menemukan dua istilah berafiks tunggal nomina ke-/-an, untuk menunjuk pada sifat. Sebenarnya, di sini terminolog Malaysia dapat saja menghindari pemungutan istilah konduksi, karena istilah kehantaran sudah hidup dalam kosa kata umum dan sebagai istilah (Labrousse 1984; Johannes dkk. 1984) dengan arti yang sama seperti kekonduksian dan keterhantaran.

Sifat hati-hati (atau konservatif?) pihak Malaysia tidak berdasarkan alasan linguistik murni, apa lagi istilah berafiks keter-/-an ditemukan dalam berbagai laman web Malaysia. Menurut studi banding yang kami kerjakan untuk bidang elektromagnetika (Samuel 2005), pada umumnya pilihan Pusat Bahasa lebih «berani» dari pada Dewan Bahasa dalam memanfaatkan potensialitas morfologis bahasa Melayu: selain kombinasi afiks, juga pemungutan afiks asing (-isasi < Bel. "-isatie" / Ing. "-ization") dan penggabungan kata dengan unsur Sanskerta lebih jarang dalam daftar istilah Malaysia. Dengan kata

26 Semua istilah sumber belum mendapat padanan dalam bahasa Indonesia. Untuk "washability test", Pusat Bahasa menerima juga uji kebersihan. 
lain, Malaysia menerima pemungutan kata/istilah, tetapi menampakkan keengganannya terhadap pemungutan tak langsung (morfologis) atau pemungutan morfem terikat. Sepertinya, terminolog dan ahli bahasa Malaysia berusaha untuk menjaga sistem morfologi bahasa Melayu sebagaimana telah diwariskan. Bahasa Melayu di Malaysia, selain status yuridisnya, mendapat kedudukan sebagai warisan luhur salah satu komponen bangsa Malaysia. Sebaliknya, sejak berabad-abad bahasa Indonesia menjadi sebuah lingua franca dan alat pemersatu: kebanyakan orang Indonesia tidak mempunyai ikatan batin yang berlebihan dengan bahasa Indonesia, dan itu membuat mereka lebih leluasa untuk bersikap inovatif.

\section{AKHIR KATA}

Pembentukan istilah melalui pemungutan terjemah tidak dianjurkan oleh aliran terminologi "klasik", ${ }^{27}$ tetapi sangat membantu, terutama bagi negaranegara yang belum dapat menyandarkan terminologinya pada sebuah literatur il-tek yang mantap dan sudah tersedia dalam bahasa nasional. Dengan afiksasi kompleks, kami menemukan semacam pemungutan terjemah yang sengaja diciptakan, dengan alasan yang ternyata lebih ideologis dari pada linguistis. Salah satu segi ideologi Orde Baru adalah pentingnya Pembangunan, dengan pembauran antara modernitas yang berasal dari luar, dan jati diri bangsa yang tentu saja berlandaskan nilai-nilai dan khazanah budaya nasional. Afiksasi kompleks justru merupakan wujud linguistis pembauran itu dan berada di persimpangan jalan antara dunia luar - ilmu dan bahasanya di dunia internasional - dan Indonesia. Terminolog Pusat Bahasa zaman Orde Baru telah mencoba untuk mengkombinasi pemungutan dan pengindonesiaan kata, dan sejak sekitar 15 tahun lalu beberapa puluhan istilah berafiks kompleks menjalani hidupnya. Maka, pertanyaan adalah: akankah istilah berafiks kompleks berumur panjang? Dapatkah prosedur itu meluas dan digunakan secara spontan oleh penutur?

Prosedur itu memang mengikuti salah satu arah perkembangan morfologi bahasa Indonesia yang cukup menjanjikan, yaitu kombinasi afiks. Tetapi di samping itu, prosedur afiksasi kompleks mempunyai kelemahan sendiri. Pertama, ambiguitas afiks ter- dan pergeseran makna tidak memungkinkan pemakai istilah untuk menentukan arti kata turunan dengan mudah. Kedua, sampai sekarang implementasi istilah resmi belum terbukti berhasil. Ketiga, beberapa ciptaan Pusat Bahasa sungguh dipaksakan dan dapat diperkirakan tidak akan bertahan lama, bahkan dengan promosi yang kuat. Apa lagi, kini Pusat Bahasa sudah semakin menyadari keterbatasan terminologi preskriptif yang sempat dijalankannya, dan sudah siap mengusahakan sebuah terminologi deskriptif yang lebih memperhatikan kebiasaan penutur bahasa dan pemakai istilah. Maka, akhirnya kami lebih cenderung melihat afiksasi kompleks sebagai suatu momentum dalam sejarah terminologi Indonesia, suatu prosedur yang sempat mewarnai perkembangan peristilahan Indonesia pada zaman Orde Baru.

27 Lihat misalnya Introduction à la terminologie (Rondeau 1984). 


\section{DAFTAR PUSTAKa}

Alieva, N.F. dkk. (red.). 1991. Bahasa Indonesia; Deskripsi dan teori. Yogyakarta: Kanisius.

Glosari sains mineral. 1994. Glosari sains mineral, perlombongan, seramik, kaca dan metalurgi; Bahasa Inggeris-Huraian-Bahasa Melayu; Bahasa Melayu-Bahasa Inggeris. Kuala Lumpur: Dewan Bahasa dan Pustaka.

Ismail, Othman dan Rogayah Hussin. 1990. Kamus fizik: elektromagnet, keelektrikan dan kemagnetan. Kuala Lumpur: Dewan Bahasa dan Pustaka.

Johannes, H., L. Wilardjo, dan H.C. Yohannes. 1984. Kamus Fisika InggrisIndonesia dengan Keterangan dalam Bahasa Indonesia. Yogyakarta: Liberty.

Kridalaksana, H. 1992. Pembentukan kata dalam Bahasa Indonesia. Jakarta: Gramedia Pustaka Utama.

Labrousse, P. 1984. Dictionnaire Général Indonésien-Français. Paris: Association Archipel.

Lukman, Ali (red.). 1991. Kamus Besar Bahasa Indonesia. Cetakan Kedua. Jakarta: Balai Pustaka.

Moeliono, Anton M (red). 1988. Kamus Besar Bahasa Indonesia. Cetakan Pertama. Jakarta: Balai Pustaka.

Moussay, G. 1995. Dictionnaire Minangkabau-Indonésien-Français. Dua Volume. Paris: L'Harmattan-Association Archipel.

Muhadjir dkk. 1996. Frekuensi kosakata Bahasa Indonesia. Depok: Fakultas Sastra Universitas Indonesia.

Prawirosusanto, S., L. Wilardjo, H.C. Yohannes. 1993. Kamus fisika: elektromagnetika. Jakarta: Pusat Pembinaan dan Pengembangan Bahasa, Departemen Pendidikan dan Kebudayaan.

Pedoman Umum. 2004. Pedoman Umum Pembentukan Istilah. Edisi Keempat. Jakarta: Pusat Bahasa. [Edisi Pertama: 1975.]

Rondeau, G. 1984. Introduction à la terminologie. Chicoutimi: Gaëtan Morin.

Samuel, J. 2001. Katalog beranotasi ensiklopedia, kamus, dan daftar istilah Bahasa Indonesia (1741 - 1995). Jakarta: Pusat Bahasa-Forum Jakarta Paris-Yayasan Obor.

Samuel, J. 2005. Modernisation lexicale et politique terminologique: le cas de l'indonésien. Louvain: Peeters.

Samuel, J. [akan terbit a.] "Traduire la trempe en indonésien ou comment faire du neuf avec du vieux". [Makalah pada Conférence Internationale sur la Traduction dans le Monde Malais, Paris, juin 2002.]

Samuel, J. [akan terbit b.] “Terminologie indonésienne du traitement thermique des métaux [terminologi perlakuan panas logam]". [présentation du domaine, terminologie et analyse des termes.]

Sneddon, J.N. 2002. Indonesian; A comprehensive grammar. London: Routledge. [Edisi Pertama: 1996.]

Steinhauer, H. 2002. Leerboek Indonesisch. Leiden: KITLV.

Stevens, Alan M. dan A.Ed. Schmidgall-Tellings. 2004. A comprehensive Indonesian-English dictionary. Athens: Ohio University Press.

Susanto, M. 1996. “Resensi Moussay 1995”, RIMA: Review of the Indonesian and 
Malaysian Affairs 30: 158-160.

Teeuw, A. 1998. De ontwikkeling van een woordenschat; Het Indonesisch 1945-1995. Amsterdam: Koninklijke Nederlandse Akademie van Wetenschappen. Teeuw, A. 1990. Indonesisch-Nederlands woordenboek. Leiden: KITLV Uitgeverij.

Tim Penyusun Kamus. 2001. Kamus Besar Bahasa Indonesia. Cetakan Ketiga. Jakarta: Balai Pustaka.

Tim Redaksi. 2008. Kamus Besar Bahasa Indonesia; Edisi Keempat. Jakarta: Gramedia Pustaka Utama.

Wilardjo, L. dan Dad Murniah. 1995. Glosarium fisika, Jakarta: Balai Pustaka, Departemen Pendidikan dan Kebudayaan.

Yohannes, H.C., A. Susanto, D. Murniah. 1996. Kamus elektronika-optoelektronika. Jakarta: Pusat Pembinaan dan Pengembangan Bahasa. 


\section{LAMPIRAN}

Istilah berafiks keter-/-an ciptaan Pusat Bahasa

Singkatan tipe afiksasi: AS "afiksasi sekunder", AKM "afiksasi kompleks morfologis", AKS "afiksasi kompleks semantis".

\begin{tabular}{|c|c|c|c|c|c|c|}
\hline Istilah Pusat Bahasa & Istilah sumber & $\begin{array}{l}\text { Bidang } \\
\text { ilmu }\end{array}$ & $\begin{array}{l}\text { Stevens and } \\
\text { Schmidgall-Tellings } \\
2004\end{array}$ & $\begin{array}{l}\text { Penelusuran } \\
\text { di Google } \\
\text { (jml. hlm.) }\end{array}$ & $\begin{array}{l}\text { Tipe } \\
\text { ter- }\end{array}$ & $\begin{array}{l}\text { Tipe } \\
\text { afiksasi } \\
\text { keter- } \\
\text { /-an }\end{array}$ \\
\hline Keterakraban & Sociability & Bio. & - & 0 & 0 & AKM \\
\hline $\begin{array}{l}\text { Keterandalan; koefisien } \\
\sim \text {; model } \sim \text {; aras } \sim \\
\text { berterima }\end{array}$ & $\begin{array}{l}\text { Reliability; } \\
\sim \text { coefficient; } \sim \text { model; } \\
\text { acceptable } \sim \text { level }\end{array}$ & Mat. & $\begin{array}{l}\text { Dependability, } \\
\text { reliability }\end{array}$ & 1.400 & 0 & AKM \\
\hline $\begin{array}{l}\text { Keterarahan; } \sim \text { bunyi; } \\
\sim \text { antena; faktor } \sim ; \\
\text { fungsi } \sim \text {; grafik } \sim ; \\
\text { indeks } \sim\end{array}$ & $\begin{array}{l}\text { Directivity; } \sim \text { of } \\
\text { sound; antenna } \sim \text {; } \\
\sim \text { factor; } \sim \text { function; } \\
\sim \text { graph; } \sim \text { index }\end{array}$ & Fis. & $\begin{array}{l}\text { Directedness, } \\
\text { being guided, } \\
\text { guiding } \\
\text { principles }\end{array}$ & 1.180 & I & AS \\
\hline $\begin{array}{l}\text { Keterasingan; koefisien } \\
\sim \text { vektor }\end{array}$ & $\begin{array}{l}\text { Alienation; vector } \\
\text { coefficient }\end{array}$ & Mat. & $\begin{array}{l}\text { Isolation, } \\
\text { exclusion, } \\
\text { alienation }\end{array}$ & 23.800 & I & AS \\
\hline $\begin{array}{l}\text { Keterbagian: lema } \sim \\
\text { koprima; } \sim \text { dua, tiga, } \\
\text { dll.; sifat } \sim \text {; uji } \sim \text {; } \\
\text { sifat } \sim\end{array}$ & $\begin{array}{l}\text { Divisibility: coprime } \\
\sim \text { lemma; } \sim \text { by two, } \\
\text { three, dll.; } \sim \text { property; } \\
\text { test for } \sim ; \sim \text { property }\end{array}$ & Mat. & Divisibility & 526 & I, III & AS \\
\hline $\begin{array}{l}\text { Keterbalikan; asas } \\
\text { dan: ketakterbalikan, } \\
\text { mikroketerbalikan }\end{array}$ & $\begin{array}{l}\text { Reversibility; } \\
\text { principle of } \\
\text { Irreversibility, } \\
\text { microreversibility }\end{array}$ & $\begin{array}{l}\text { Fis. } \\
\text { Bio. }\end{array}$ & - & 1.350 & I, II & AKS \\
\hline Keterbasahan & Wettability & Kim. & - & 3 & 0 & AKM \\
\hline Keterbatasan & Boundedness & Mat. & $\begin{array}{l}\text { Limitation, being } \\
\text { limited }\end{array}$ & 630.000 & I & AS \\
\hline Keterbauran & Diffusivity & Fis. & Diffusivity & 33 & I & AKS \\
\hline $\begin{array}{l}\text { Keterbedaan } \\
\text { dan: ketakterbedaan }\end{array}$ & $\begin{array}{l}\text { Distinguishability } \\
\text { Indistinguishability }\end{array}$ & Fis. & - & 27 & $\begin{array}{l}\text { III } \\
(-k a n ?)\end{array}$ & AS \\
\hline Keterbelahan & Fissionability & Fis. & $\begin{array}{l}\text { Being split } \\
\text { (in intention), } \\
\text { irresoluteness }\end{array}$ & 2.410 & $\begin{array}{l}\text { I; III } \\
(-k a n)\end{array}$ & AS \\
\hline $\begin{array}{l}\text { Ketercacahan: aksioma } \\
\sim ; \text { aksioma pertama } \sim\end{array}$ & $\begin{array}{l}\text { Countability: axiom } \\
\text { of } \sim \text {; first axiom of } \sim\end{array}$ & Mat. & Countability & 1 & I & AKS? \\
\hline $\begin{array}{l}\text { Ketercampuran } 1 \text {; suhu } \\
\sim \text { kritis } \\
\text { Ketercampuran } 2\end{array}$ & $\begin{array}{l}\text { Miscibility; critical } \\
\text { temperature } \\
\text { Mixedness }\end{array}$ & $\begin{array}{l}\text { Fis. } \\
\text { Kim. }\end{array}$ & - & 35 & I & $\begin{array}{l}\text { AKS } \\
\text { AS }\end{array}$ \\
\hline Ketercernaan; protein & $\begin{array}{l}\text { Digestibility; of } \\
\text { protein }\end{array}$ & $\begin{array}{l}\text { Bio. } \\
\text { Kim. }\end{array}$ & Digestibility & 16 & I, III & AS \\
\hline Ketercetakan & Printability & Kim. & - & 5 & I & AKS \\
\hline Ketercucian: uji & Washability test & Kim. & - & 25 & I & AKS \\
\hline $\begin{array}{l}\text { Keterdengaran; ranah } \\
\sim \text {-janggal; lengkung } \sim \text {; } \\
\text { ambang }\end{array}$ & $\begin{array}{l}\text { Audibility; } \\
\text { anomalous zone of } \sim \\
\sim \text { curve; } \sim \text { threshold }\end{array}$ & $\begin{array}{l}\text { Fis. } \\
\text { Bio. }\end{array}$ & $\begin{array}{l}\text { Hearing (sens), } \\
\text { audibility }\end{array}$ & 57 & III & AS \\
\hline Keterdiagonalan & Diagonalizability & Mat. & - & 1 & $?$ & AKM \\
\hline
\end{tabular}




\begin{tabular}{|c|c|c|c|c|c|c|}
\hline Istilah Pusat Bahasa & Istilah sumber & $\begin{array}{l}\text { Bidang } \\
\text { ilmu }\end{array}$ & $\begin{array}{l}\text { Stevens and } \\
\text { Schmidgall-Tellings } \\
2004\end{array}$ & $\begin{array}{l}\text { Penelusuran } \\
\text { di Google } \\
\text { (jml. hlm.) }\end{array}$ & $\begin{array}{l}\text { Tipe } \\
\text { ter- }\end{array}$ & $\begin{array}{l}\text { Tipe } \\
\text { afiksasi } \\
\text { keter- } \\
\text { /-an }\end{array}$ \\
\hline $\begin{array}{l}\text { Keterdiferensialan: } \\
\text { stokastik }\end{array}$ & $\begin{array}{l}\text { Differentiability: } \\
\text { stochastic } \sim\end{array}$ & Mat. & - & 5 & ? & AKM \\
\hline Keterendapan & Precipitability & Kim. & - & 4 & I (?) & AKS \\
\hline Ketergandaan & Multiplicity & Fis. & - & 1 & $?$ & AKM \\
\hline $\begin{array}{l}\text { Ketergantungan: } \\
\text { kontinu; kuadran; } \\
\text { nisbah kemungkinan; } \\
\sim \text { linear; } \sim \text { numeris; } \\
\text { regresi; stokastik; } \\
\text { kerapatan inversi }\end{array}$ & $\begin{array}{l}\text { Dependence: } \\
\text { continuous } \sim \text {; } \\
\text { quadrant } \sim ; \\
\text { likehood ratio } \sim \text {; } \\
\text { linear } \sim \text {; numerical } \\
\sim \text {; regression } \sim \text {; } \\
\text { stochastic } \sim \text {; inverse } \\
\text { density } \sim\end{array}$ & $\begin{array}{l}\text { Mat. } \\
\text { Bio. }\end{array}$ & Dependence & 248.000 & I & AS \\
\hline $\begin{array}{l}\text { Keterhambatan; } \\
\text { janggal [anormal]; } \\
\sim \text { elektris; elektris } \\
\text { saput; alir; termal } \\
\text { kekisi; model tiga- } \\
\text { lapis; termal; } \\
\text { kentara nisbi; saki; } \\
\text { dll. }\end{array}$ & $\begin{array}{l}\text { Resistivity; } \\
\text { anomalous } \sim \text {; } \\
\text { electrical } \sim \text {; electrical } \\
\sim \text { of films; flow } \sim \text {; } \\
\text { lattice thermal } \sim \text {; } \\
\text { three-layer } \sim \text { modes; } \\
\text { thermal } \sim \text {; relative } \\
\text { apparent } \sim \text {; residual } \\
\sim \text {, dll. }\end{array}$ & Fis. & Resistivity & 848 & I & AKS \\
\hline $\begin{array}{l}\text { Keterhantaran 1; } \\
\sim \text { kentara; kurva } \\
\sim \text {-kentara; buli; } \\
\text { hablur ion; batas } \sim \text {; } \\
\sim \text { plasma; suhu } \sim \text {; } \\
\text { termal; elektrik; }\end{array}$ & $\begin{array}{l}\text { Conductivity; } \\
\text { apparent } \sim \text {; } \\
\text { apparent- curve; } \\
\text { bulb } \sim \sim \text { ionic crystal; } \\
\sim \text { limit; } \sim \text { of plasma; } \\
\text { temperature; thermal }\end{array}$ & Fis. & - & 78 & $\mathrm{I}(?)$ & AKS? \\
\hline $\begin{array}{l}\text { elektris; } \sim \text { termal } \\
\text { elektron; } \sim \text { bahang; } ~ \\
\text { takmurnian; air; } ~ \\
\text { bahang; } \sim \text { menyinar, } \\
\text { dll. } \\
\text { Keterhantaran 2; } \\
\text { diferensial negatif } \\
\text { dan: } \\
\text { magnetoketerhantaran, } \\
\text { fotoketerhantaran, } \\
\text { piroketerhantaran, } \\
\text { adiketerhantaran, } \\
\text { keteradihantaran, } \\
\text { keadihantaran, } \\
\text { adihantaran }\end{array}$ & $\begin{array}{l}\sim \text {; electric } \sim \text {; electrical } \\
\sim \text {; electronic thermal } \\
\sim \text {; heat } \sim \text {; impurity } \sim \text {; } \\
\text { water } \sim \text {; thermal } \sim \text {; } \\
\text { radiative } \sim \text {, dll. } \\
\text { Conductance: } \\
\text { negative differential } \sim \\
\text { Magnetoconductivity, } \\
\text { photoconductivity, } \\
\text { pyroconductivity, } \\
\text { supraconductivity }\end{array}$ & & & & & \\
\hline $\begin{array}{l}\text { Keterhidupan } \\
\text { [keterhidupanan }(\text { sic)] }\end{array}$ & Viability & Bio. & Viability & 0 & ? & AKM \\
\hline $\begin{array}{l}\text { Keterhinggaan } \\
\text { dan: ketakterhinggaan }\end{array}$ & $\begin{array}{l}\text { Finiteness } \\
\text { Infinity }\end{array}$ & Mat. & - & 19 & $?$ & AS \\
\hline $\begin{array}{l}\text { Keterhubungan 1: } \\
\text { garis } \\
\text { Keterhubungan 2: } \\
\text { rantai }\end{array}$ & $\begin{array}{l}\text { Connectivity: line } ~ \\
\text { Connectedness: } \\
\text { chain- }\end{array}$ & Mat. & $\begin{array}{l}\text { Connectedness, } \\
\text { relatedness, } \\
\text { relationship }\end{array}$ & 9.500 & I & $\begin{array}{l}\text { AKS } \\
\text { AS }\end{array}$ \\
\hline Keteridentifikasian & Identifiability & Bio. & - & 1 & I & AKS \\
\hline Keterimpitan: titik & Coincidence: $\sim$ point & Mat. & - & 23 & I, II (?) & AS ? \\
\hline
\end{tabular}




\begin{tabular}{|c|c|c|c|c|c|c|}
\hline Istilah Pusat Bahasa & Istilah sumber & $\begin{array}{l}\text { Bidang } \\
\text { ilmu }\end{array}$ & $\begin{array}{l}\text { Stevens and } \\
\text { Schmidgall-Tellings } \\
2004\end{array}$ & $\begin{array}{l}\text { Penelusuran } \\
\text { di Google } \\
\text { (jml. hlm.) }\end{array}$ & $\begin{array}{l}\text { Tipe } \\
\text { ter- }\end{array}$ & $\begin{array}{l}\text { Tipe } \\
\text { afiksasi } \\
\text { keter- } \\
\text { /-an }\end{array}$ \\
\hline $\begin{array}{l}\text { Keterintegralan; } \\
\text { stokastik }\end{array}$ & $\begin{array}{l}\text { Integrability; } \\
\text { stochastic } \sim\end{array}$ & Mat. & - & 4 & $?$ & $\mathrm{AKM}$ \\
\hline Keterjangkauan & Reachability & Mat. & $\begin{array}{l}\text { Affordability, } \\
\text { attainability }\end{array}$ & 8.760 & III & AS \\
\hline Keterjumlahan: abel & Summability: abel & Mat. & - & 2 & $\begin{array}{l}\text { I; III } \\
(-k a n ?)\end{array}$ & AS? \\
\hline Keterkaitan: klausa & Lien: clause & Mat. & $\begin{array}{l}\text { Linkage, } \\
\text { interconnection, } \\
\text { involvement, } \\
\text { relevance, } \\
\text { relatedness }\end{array}$ & 168.000 & I & AS \\
\hline $\begin{array}{l}\text { Keterkutuban; ikat; } \\
\text { elektronik; tensor } \\
\sim \text { rampat; } \sim \text { kiblat; } \\
\text { pergeseran } \sim \text {; } \\
\text { hidrogen; ion } \\
\text { dan: } \\
\text { keterkutubantensoran }\end{array}$ & $\begin{array}{l}\text { Polarizability; bond } \\
\sim \text {; electronic } \sim \text {; } \\
\text { generalized } \sim \text { tensor; } \\
\text { orientational } \sim ; \sim \\
\text { displacement; } \sim \text { of } \\
\text { hydrogen; ion } \sim \\
\text { Tensor } \sim\end{array}$ & $\begin{array}{l}\text { Fis. } \\
\text { Bio. } \\
\text { Kim. }\end{array}$ & - & 80 & $\mathrm{I} ?$ & AKS? \\
\hline Keterlaksanaan: studi & Feasibility: study & $\begin{array}{l}\text { Kim. } \\
\text { Bio. }\end{array}$ & Feasibility & 1.790 & I, III & AS \\
\hline Keterlaraian; $\sim$ kanta & $\begin{array}{l}\text { Resolution; power } \\
\text { [of a lens], resolving } \\
\text { power [lens] }\end{array}$ & Fis. & - & 6 & I & AS \\
\hline $\begin{array}{l}\text { Keterlarutan; uji } \sim \text {; uji } ~ \\
\text { empedu; koefisien } \\
\text { dan: keterlewatlarutan }\end{array}$ & $\begin{array}{l}\text { Solubility; } \sim \text { test; bile } \\
\sim \text { test; coefficient } \\
\text { Supersolubility }\end{array}$ & Fis. & - & 617 & $\begin{array}{l}\text { I; III } \\
(-k a n ?)\end{array}$ & AS \\
\hline $\begin{array}{l}\text { Ketermampatan; } \\
\text { adiabatik; koefisien } \\
\sim \text {; persamaan } \sim ; \\
\text { isoterm }\end{array}$ & $\begin{array}{l}\text { Compressibility; } \\
\text { adiabatic } \sim \sim \\
\text { coefficient; } \sim \\
\text { equation; isothermal } \\
\sim\end{array}$ & $\begin{array}{l}\text { Fis. } \\
\text { Kim. }\end{array}$ & Compressibility & 65 & I & AKS \\
\hline Ketermodifikasian & modificability & Bio. & - & 0 & I & AKS \\
\hline $\begin{array}{l}\text { Ketermuatan: } \\
\text { pemaduan } \sim\end{array}$ & $\begin{array}{l}\text { Chargeability: } \\
\text { integration of } \sim\end{array}$ & Fis. & - & 6 & $\begin{array}{l}\text { I, III } \\
(-k a n ?)\end{array}$ & AS ? \\
\hline $\begin{array}{l}\text { Keterpancaran; } \\
\sim \text { ekawarna } \\
\text { [monokromatik]; } \\
\text { spektrum }\end{array}$ & $\begin{array}{l}\text { Emissivity; } \\
\text { monochromatic } \sim \text {; } \\
\text { spectral } \sim\end{array}$ & Fis. & - & 6 & I, II & AKS \\
\hline $\begin{array}{l}\text { Keterpantulan } 1 ; \sim \\
\text { akustik; } \sim \text { inframerah; } \\
\sim \text { hablur ion; } \sim \text { masuk- } \\
\text { sadak } \\
\text { Keterpantulan } 2: \sim \\
\text { rerata; } \sim \text { spekular; } \\
\text { keterpantulan } \sim\end{array}$ & $\begin{array}{l}\text { Reflectivity; acoustic } \\
\sim \text {; infrared } \sim \text {; ionoc } \\
\text { crystals } \sim \text {; oblique- } \\
\text { incidence } \sim \\
\text { Reflectance: average } \\
\sim \text {; specular } \sim \text {; spectral } \\
\sim\end{array}$ & Fis. & - & 54 & I & $\begin{array}{l}\text { AKS } \\
\text { AS }\end{array}$ \\
\hline Keterpilinan & Helicity & Fis. & - & 1 & I & AS? \\
\hline Keterputihan & Bleachibility & Kim. & - & 0 & 0 & $\mathrm{AKM}$ \\
\hline
\end{tabular}




\begin{tabular}{|c|c|c|c|c|c|c|}
\hline Istilah Pusat Bahasa & Istilah sumber & $\begin{array}{l}\text { Bidang } \\
\text { ilmu }\end{array}$ & $\begin{array}{l}\text { Stevens and } \\
\text { Schmidgall-Tellings } \\
2004\end{array}$ & $\begin{array}{l}\text { Penelusuran } \\
\text { di Google } \\
\text { (jml. hlm.) }\end{array}$ & $\begin{array}{l}\text { Tipe } \\
\text { ter- }\end{array}$ & $\begin{array}{l}\text { Tipe } \\
\text { afiksasi } \\
\text { keter- } \\
\text { /-an }\end{array}$ \\
\hline $\begin{array}{l}\text { Ketereduksian } \\
\text { dan: ketaktereduksian } \\
\text { (kriteria } \sim \text { Eisenstein) }\end{array}$ & $\begin{array}{l}\text { Reducibility } \\
\text { Irreducibility } \\
\text { (Eisenstien } \\
\text { criterion) }\end{array}$ & Mat. & - & 2 & $?$ & $\mathrm{AKM} ?$ \\
\hline Ketersalinan & Reproducibility & Mat. & - & 3 & I & AKS \\
\hline Ketersaringan & Filtrability & Kim. & - & 2 & I & AKS \\
\hline $\begin{array}{l}\text { Ketersediaan: } \sim \text { usaha; } \\
\text { fungsi } \sim ; \text { tandon } \\
\text { bahang; } \sim \text { fosforus }\end{array}$ & $\begin{array}{l}\text { Availability: } \sim \text { of } \\
\text { work; } \sim \text { function; } \sim \\
\text { of heat reservoirs; } \\
\text { phosphorus } \sim\end{array}$ & $\begin{array}{l}\text { Fis. } \\
\text { Kim. }\end{array}$ & Availability & 407.000 & I & AS \\
\hline $\begin{array}{l}\text { Keterselesaian: } \\
\sim \text { kongruen }\end{array}$ & $\begin{array}{l}\text { Solvability: } \\
\sim \text { of congruence }\end{array}$ & Mat. & - & 19 & $\begin{array}{l}\text { I, III } \\
(-k a n)\end{array}$ & AS \\
\hline Keterserapan; jenis & $\begin{array}{l}\text { Absorptivity; specific } \\
\sim\end{array}$ & $\begin{array}{l}\text { Fis. } \\
\text { Kim. }\end{array}$ & $\begin{array}{l}\text { Absorption, } \\
\text { absorbability }\end{array}$ & 1.290 & I & AKS \\
\hline Ketersimpangan & Deviance & Mat. & - & 1 & I & AS \\
\hline Ketertapisan & Filtrability & Bio. & - & 2 & I & AKS \\
\hline Ketertempaan & Malleability & Kim. & - & 5 & $\begin{array}{l}\text { I, III } \\
(-k a n)\end{array}$ & AS \\
\hline Keterulangan & Reproducibility & $\begin{array}{l}\text { Kim. } \\
\text { Bio. }\end{array}$ & Repetition & 277 & I & AS \\
\hline Keteruraian & Decomposability & Mat. & Decomposability & 19 & I & AKS \\
\hline $\begin{array}{l}\text { Keterwarisan } \\
{[\text { keterwarisanan }(\mathrm{sic})]} \\
\sim \text { luas }\end{array}$ & Heritability; broad & Bio. & - & 4 & $?$ & AKM \\
\hline
\end{tabular}

